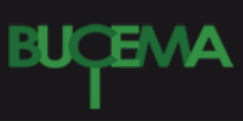

Bulletin du centre d'études médiévales d'Auxerre | BUCEMA

Hors-série $n^{\circ} 6 \mid 2013$

Autour du cloître : les chapelles Notre-Dame et les accès au chapitre

\title{
La chapelle Saint-Benoît de Fontevraud
}

Daniel Prigent

\section{(2) OpenEdition}

Journals

Édition électronique

URL : https://journals.openedition.org/cem/12920

DOI : $10.4000 /$ cem. 12920

ISSN : 1954-3093

Éditeur

Centre d'études médiévales Saint-Germain d'Auxerre

Référence électronique

Daniel Prigent, «La chapelle Saint-Benoît de Fontevraud », Bulletin du centre d'études médiévales d'Auxerre | BUCEMA [En ligne], Hors-série n 6 | 2013, mis en ligne le 09 avril 2013, consulté le 03 mars 2023. URL : http://journals.openedition.org/cem/12920 ; DOI : https://doi.org/10.4000/cem.12920

Ce document a été généré automatiquement le 3 mars 2023.

\section{(c) (i) (2)(2)}

Creative Commons - Attribution - Pas d'Utilisation Commerciale - Partage dans les Mêmes Conditions 4.0 International - CC BY-NC-SA 4.0

https://creativecommons.org/licenses/by-nc-sa/4.0/ 


\section{La chapelle Saint-Benoît de Fontevraud}

\section{Daniel Prigent}

1 (à paraître)

AUTEUR

DANIEL PRIGENT

Conseil général du Maine-et-Loire 